\title{
THE UTILIZATION OF REMOTE SENSING AND GEOGRAPHIC INFORMATION SYSTEMS FOR MONITORING DAMAGE OF THE MANDOR NATURAL RESERVES IN WEST KALIMANTAN PROVINCE
}

\author{
Ajun Purwanto ${ }^{1}$, Dony Andrasmoro ${ }^{2}$ \\ ${ }^{1,2}$ Geography Education, IKIP PGRI Pontianak \\ Email: ajunpurwanto@ikippgriptk.ac.id
}

\begin{abstract}
This study aims to determine the level of damage to the protected area of the Mandor Nature Reserve in 2019 by utilizing Remote Sensing and Geographical Information Systems. The method used in this research is secondary data analysis. The data used are the boundaries, area, condition of the Nature Reserve area, and landscape imagery 8. The data collection technique uses secondary data interpretation, while the tools used are Landsat Image 8. The data analysis technique uses the Geographic Information System with ArcGis 10.2.2 software. The results of interpretation of Landsat 8 images recorded on July 5, 2019, and analysis using Arcgis 10.2.2, it is known that from the total forest area of 3.080 ha, the condition of the Nature Reserve is 2,052, 327 ha are still in good condition or have not been damaged, 234,443 ha are lightly damaged, 66,421 ha moderately damaged and 726,809 Ha heavily damaged. Most of the damage to protected areas in the form of Nature Reserve forests was caused by illegal mining activities, namely unauthorized gold mining, forest fires, and forest encroachment or cultivation.
\end{abstract}

Keywords: Remote Sensing; Geographic Information System; Monitoring; Nature Reserve

\section{A. INTRODUCTION}

A nature Reserve is a form of the protected area which is designated with the aim of protecting the ecosystem or conserving the ecosystem. Nature reserves can also be used in tourism development, especially ecotourism. Apart from being a protected area that functions to protect the ecosystem, what must always be paid attention to by conservation area managers is the benefits of the area as the development of biodiversity and management of its ecosystem (Nordiansyah, 2016). Protected areas are also useful for restoring degraded ecosystems and conserving biodiversity (Mashizi \& Sharafatmandrad, 2020).

Therefore, the protected area needs to be protected from damage so that it does not become a complex problem. Livestock grazing, logging, harvesting of crops and other uses are prohibited in the Nature Reserve area (Tesfaye, Bekele, Kebede, Tefera, \& Kassa, 2015; Verdoodt, Mureithi, \& Van Ranst, 2010) especially mining activities. Therefore, for the successful management of protected areas, it is very important to instill understanding and equalize the 
perceptions of the population in nature conservation (Mitsui, Kubo, \& Shoji, 2020).

Maintaining the functions of protected areas such as biodiversity conservation, participation, and support to manage the people living in and around protected areas is very important (Mitsui et al., 2020; Oldekop, Holmes, Harris, \& Evans, 2016). However, several cases of failure of protected areas are maintained due to lack of citizen participation, which disturbs the balance of the ecosystem (Andrade \& Rhodes, 2012; Mitsui et al., 2020; Soliku \& Schraml, 2018).

One of these cases also occurred in the protected area of the Mandor Nature Reserve. Mandor Nature Reserve has 3,080 ha located in Mandor District, Landak Regency, West Kalimantan. There are three types of ecosystems that exist in this area, namely the type of peat swamp ecosystem, the lowland ecosystem, and the shell ecosystem. Since the Dutch colonial era in 1936, this area has been designated as a protected area. The West Kalimantan Natural Resources Conservation Center recorded the various types of fauna that live here. There are Sun Bears, Mouse Deer, Binturong, Weasels, Hedgehogs, and Hornbills (Adirahmanta, 2020).
Another potential of biodiversity in the Mandor Nature Reserve is the presence of various local plants. This area is dominated by Shorea, Rengas, Jelutung, Tengkawang, and Ramin species, as well as carnivorous plants such as Nepenthes ampularia, Nepenthes mirabilis, Nepenthes gracilis, and Nepenthes bicalcarata. In addition to that, the types of orchids that have stolen the public's attention include the Black Orchid which was once viral for its beauty, the Ground Orchid, the Elephant Ear Orchid, the Cane Orchid, and the Candle Orchid (Ratnawati, 2020).

Unfortunately, the changes in land cover in the Mandor Nature Reserve are becoming increasingly worrying. The area that was originally green has now become a stretch of white sand like a dessert that is increasingly expanding. This change is due to the loss of vegetation with a thick canopy as a blanket of the area. The Nature Reserve area has been turned into a stretch of white sand due to illegal gold mining. Protected areas are actually a key strategy for protecting biological resources, but their effectiveness varies widely and is often affected by the negative activities of local communities (Oldekop et al., 2016).

This condition needs to be monitored continuously to maintain the 
preservation of the protected area of the Mandor Nature Reserve. One of the efforts to facilitate monitoring of the area is by utilizing Remote Sensing technology and Geographical Information Systems (GIS). Remote sensing has the ability to record the earth's surface with a large area in the recording time without direct physical contact with the object (Rahayu, 2017).

The development of remote sensing platforms and sensors as well as GIS science and technology provides important support for monitoring protected areas around the world, especially in Indonesia. Monitoring with of Remote Sensing and GIS can provide important information for efficient, transparent, repeatable, and maintainable decision making at the protected level of management and governance (Wang, Lu, Sheng, \& Zhou, 2020).

Remote sensing data products, coupled with easy to use data exploration, analysis, and modeling tools with accessible GIS, enable scientists and practitioners to gain a better understanding of how environmental changes affect species populations, ecosystem functions, and the services that sustain them (Fancy, Gross, \& Carter, 2009; Gross, Goetz, \& Cihlar, 2009;
Wang et al., 2020). Remote sensing applications have contributed a lot to the inventory and monitoring efforts (Wang et al., 2009, 2020) as well as the support of Geographical Information Systems (GIS).

To take advantage of Remote Sensing and GIS technology, the authors conducted research in the protected area of the Mandor Nature Reserve with the aim of knowing the level of damage to the Nature Reserve protected area.

\section{B. MATERIALS AND METHODS}

\section{Study Area}

This research was conducted in the protected area of Mandor Nature Reserve, which is located in the Mandor subdistrict, Landak district, West Kalimantan province. The study area has an area of 3,080 ha. This area was used as a protected area in the form of a Nature Reserve since the Dutch era, namely 1936. This area is managed by the Ministry of Forestry through the West Kalimantan Natural Resources Conservation Center. The study area of the protected area of the Mandor Nature Reserve can be seen in Figure 1. 


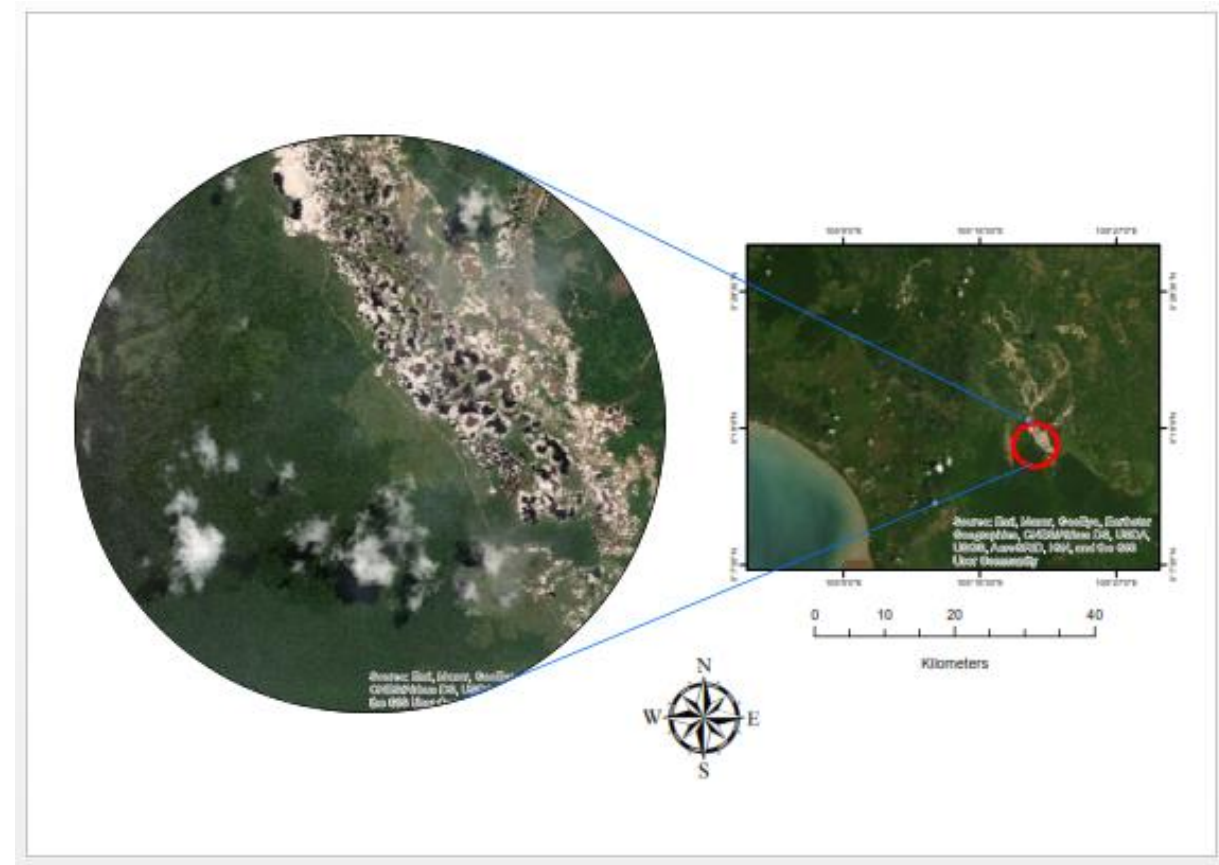

Figure 1. Study Area

\section{Data Collection}

The method used in this research is secondary data analysis. The data collected includes the area and boundaries of the study area, the condition of the protected area of the Nature Reserve, and Landsat 8 imagery recorded on July 5, 2019. The data collection technique uses an interpretation of Landsat 8 images and documentary studies.

\section{Data analysis}

Data analysis techniques used Geographic Information Systems (Munir, Atmosoemarto, \& Arifien, 2019; Nahib \& Wijaya, 1999). The band combination used for processing Landsat 8 image data is a 4-3-2 (natural color) band combination (Munir et al., 2019). The software used for this analysis is ArcGis 10.2.2. To simplify the analysis, the authors sharpen the Landsat 8 visualization with the Pan Sharping process, which combines a 4-3-2 composite image with band 8 (panchromatic), by utilizing the Data Management toll on the raster.

\section{RESULTS AND DISCUSSION}

The condition of the forest in Mandor since its establishment as a Nature Reserve in 1936 has continued to change due to illegal gold mining activities. The condition of the Mandor Nature Reserve forest based on the interpretation of the 2013 Landsat imagery can be seen in Figure 2. 


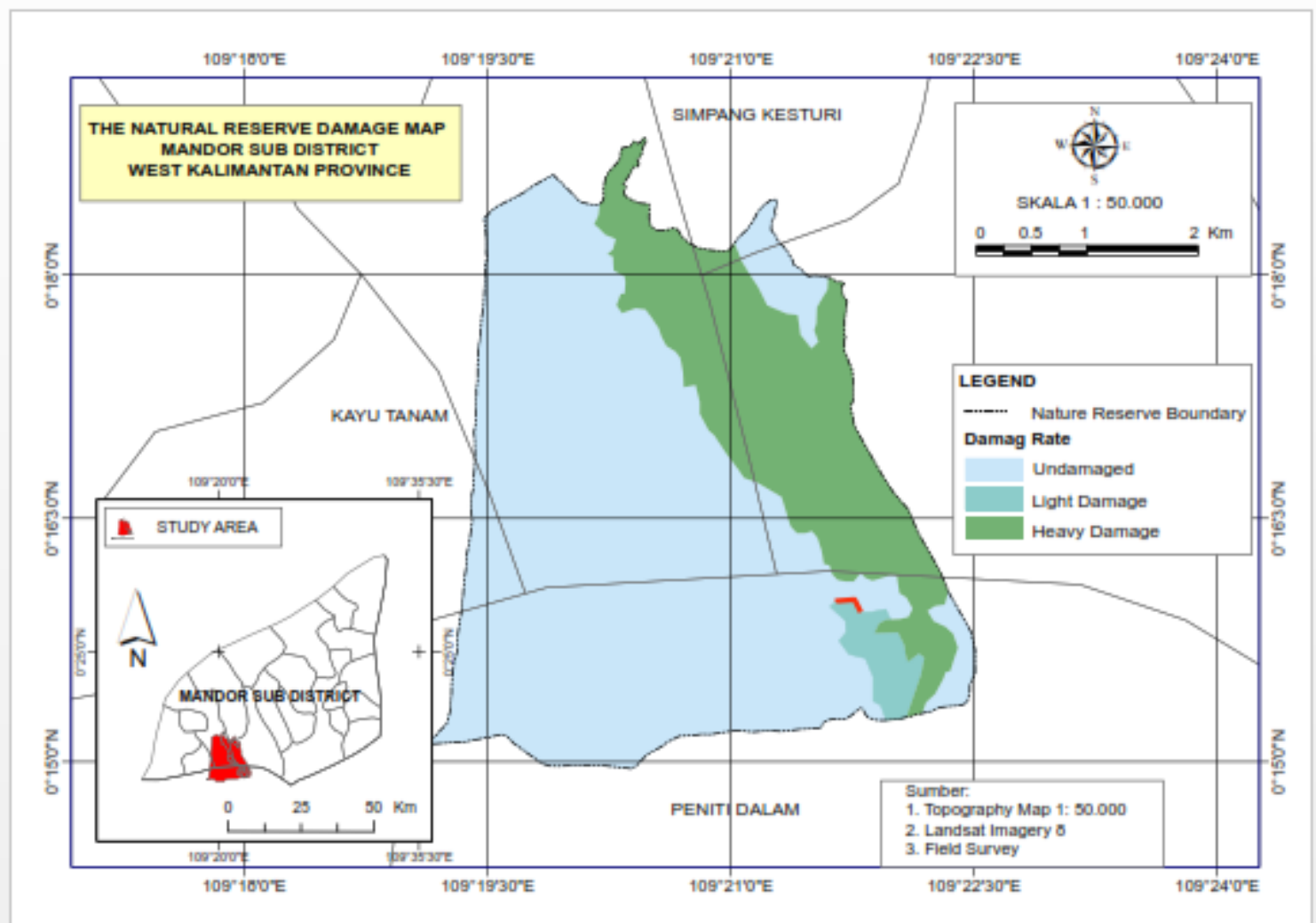

Figure 2. The Past Condition of the Mandor Nature Reserve

In order to facilitate the analysis of the Landsat 8 image in this study, band mergers or combinations were carried out. This is done with the aim of making it easier to identify, interpret, and analyze the area to be studied. Merging channels or bands from Landsat 8 satellite imagery is carried out on 3 bands. The format used in this band merger is RGB (Red Green Blue). The image generated from this combination process is a "true color" image. The true color is the color that results from joining the bands whose results are the same color as what the human eye sees. To produce true color images in this study, used by the bands 432.

The process of merging these bands utilizes ArcGis 10.2.2 by using the Data segmentation toll, Raster, Raster Processing, and Raster Composite facilities. The band combination process in Landsat 8 was selected using the bands 432. The results of this process obtained a composite 432 image and the color obtained was the true color. This means that the color we see in the image is the same as the color seen with the ordinary eye. To further clarify the visualization of the image, a Pan-Sharpened Raster 
process was carried out. The Pan-

Sharpened Raster process is carried out by utilizing the 432 composite images that have been generated from the previous process with Landsat8 imagery on band 8 which is commonly called the panchromatic band.
The results of the process of combining or merging bands with RGB 432 and Pan-Sharpened Raster with channel 8 or Panchromatic above can be seen in Figure 3.

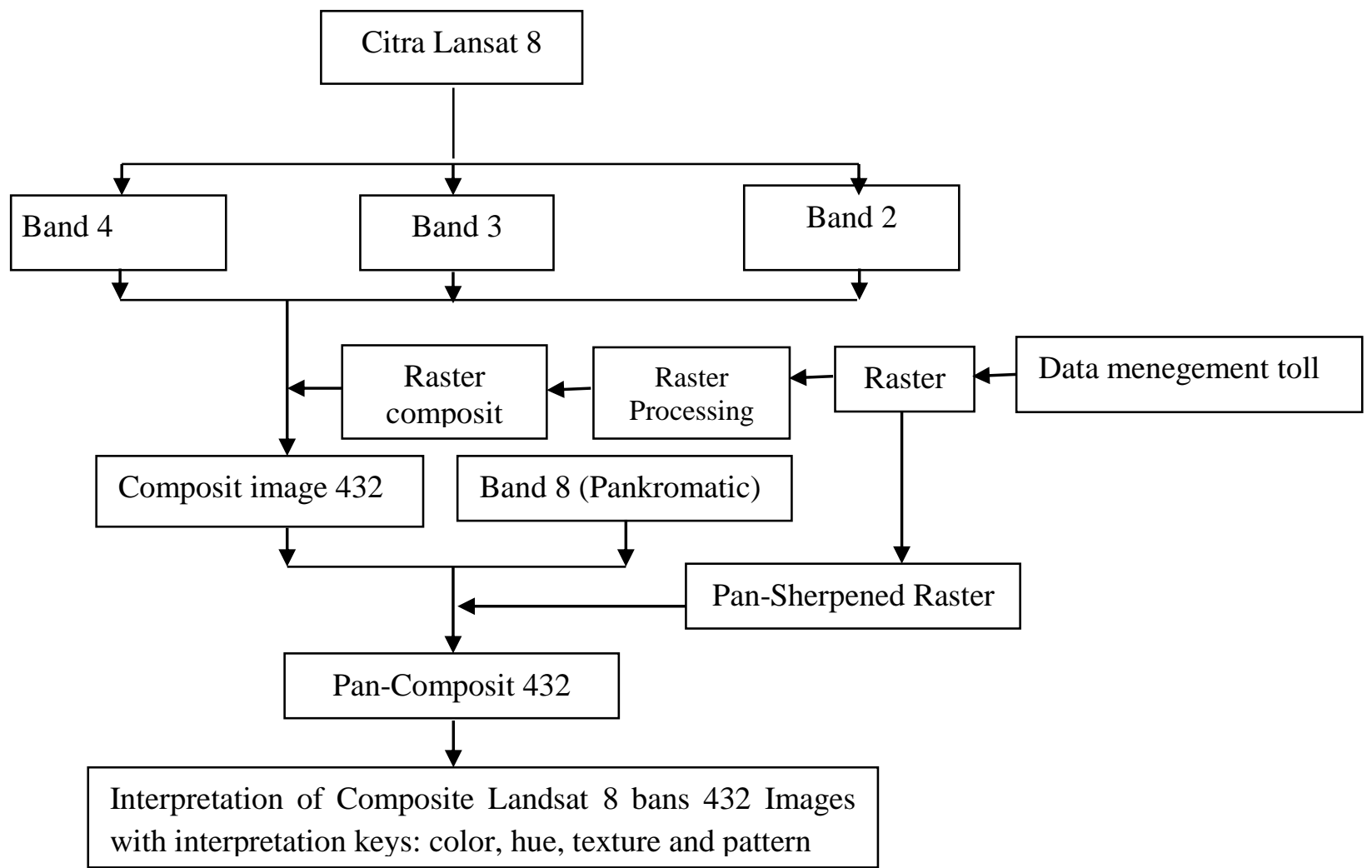

Figure 3. The Process of Combining and Interpreting Landsat Images 8

The interpretation of Landsat 8 image combination bands of 432 in this research area uses interpretation keys, among others, color, hue, texture, and pattern. Based on the combined image of band 432 and the result of the PanSharpened Raster, it can be clearly identified the locations of the protected areas of the Mandor Nature Reserve that have been damaged and which have not been damaged. As a protected area, the green color should be visible throughout the area. However, this condition is not found in all protected areas of the Mandor Nature Reserve. Some of the Nature Reserve areas have changed their color to 
other colors, such as white, gray, brown, and black.

These colors indicate that some of the protected areas have been damaged. The green color indicates the presence of vegetation. The greener the color in the image indicates the vegetation is getting thicker and that means the area has not been damaged. The gray color indicates the presence of minor damage, the blueblack color indicates inundation and moderate damage. This is due to illegal gold mining activities in the nature reserve area. Areas that are heavily damaged have a light hue. Light colors indicate that an object is made up of many different materials. These different materials cause differences in the ability to reflect sunlight back both in quality and intensity.

Another characteristic of the Landsat 8 combination band 432 image is the texture in the image. Texture is a combination of hues, size, and distance. The interpretation results show that the texture of the area which is slightly coarse indicates mild to moderate damage, while the rough texture indicates that the Nature Reserve has suffered heavy damage. The difference in the roughness of the objects in the Nature Reserve area is due to differences in land use and land cover (LULC).

Judging from the pattern of objects, the damaged areas tend to cluster and elongate patterns. This elongated and clustered pattern can be seen on the east side of the Nature Reserve area. This condition indicates that the damage to the Nature Reserve is caused by human activities that tend to be carried out openly and allows the involvement of many actors. It is different if the pattern spreads, it could be because the exploitation is carried out secretly and on a small scale with the aim of avoiding the manager.

From the above characteristics, by using GIS and Remote Sensing, the level of damage to the Mandor Nature Reserve can be known. Based on the results of the interpretation and calculation results of the Landsat 8 combination of band 432, it is known that from the total area of 3.080 Ha, the condition of the Nature Reserve is 2,052, 327 ha is still in good condition or has not been damaged, 234,443 $\mathrm{Ha}$ is lightly damaged, 66,421 Ha is moderately damaged and $726,809 \mathrm{Ha}$ is damaged the weight. 
Table 1. Area and Degree of Damage to the Mandor Nature Reserve

\begin{tabular}{ccc}
\hline No & Damage Level & Area (Ha) \\
\hline 1. & Undamaged & $2.052,327$ \\
2. & Light Damage & 234,443 \\
3. & Moderate Damage & 66,421 \\
4. & Heavy Damage & 726,809 \\
& Total & $3.080,000$ \\
\hline
\end{tabular}

Source: Results of Landsat 8 Band 432 Interpretation Imagery

Based on the data above, the level of damage to the Mandor Nature Reserve can be mapped as shown in Figure 4.

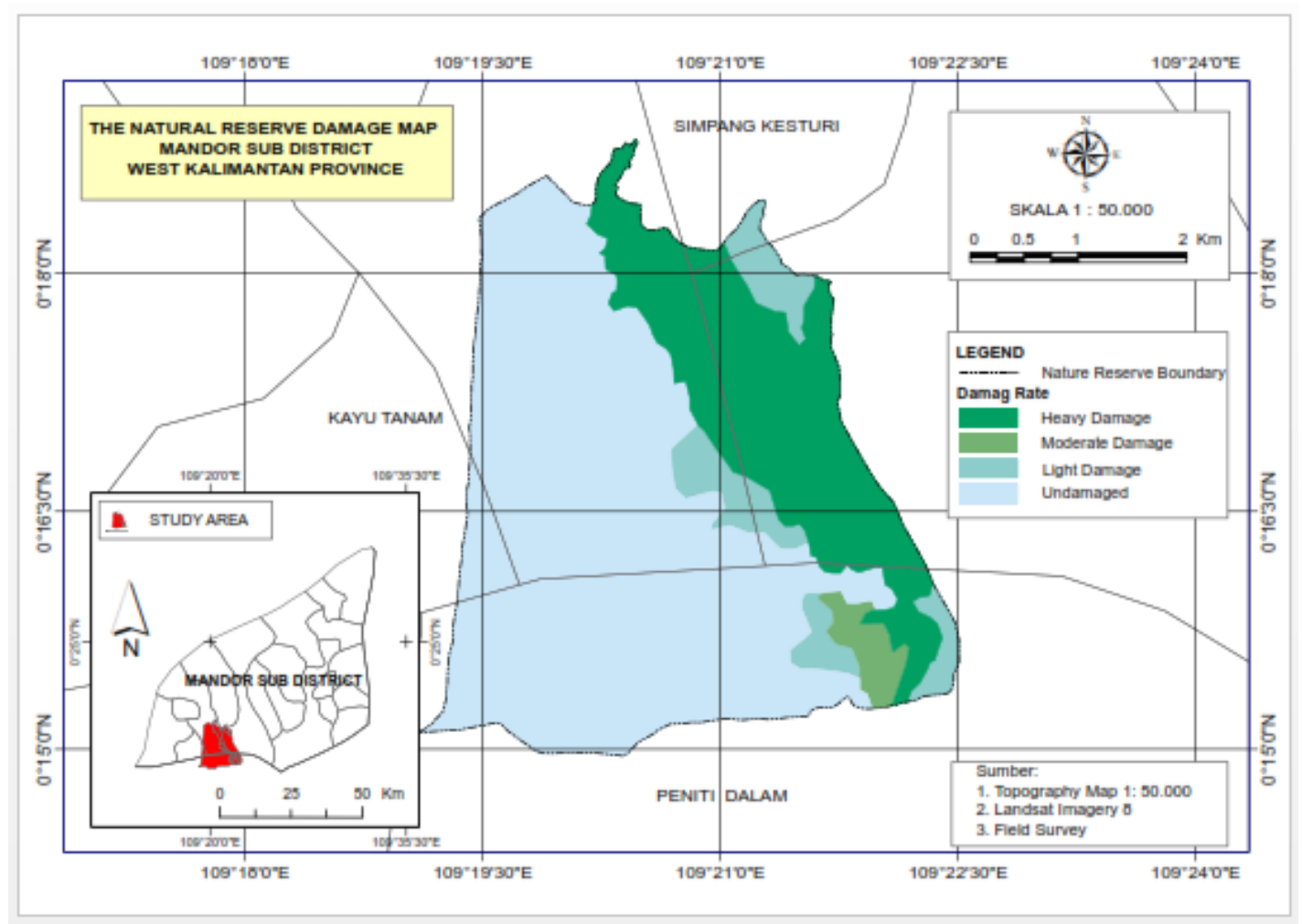

Figure 4. Current Condition of The Mandor Nature Reserve

\section{CONCLUSIONS}

Based on the results of research on the protected area of the Mandor Nature Reserve, it can be concluded that the use of Remote Sensing technology and Geographical Information Systems (GIS) is very helpful in monitoring protected areas, one of which is the Nature Reserve.
PJ and SIG also have enormous benefits in identifying the level of damage to Nature Reserve protected areas. Based on the interpretation, $33.36 \%$ of the protected areas of the Mandor Nature Reserve have suffered damage, both moderate and severe levels. Most of the damage to protected areas in the form of 
Nature Reserve forests is due to illegal mining activities, namely illegal gold mining as well as forest fires, and forest encroachment or cultivation.

\section{E. REFERENCES}

Adirahmanta. (2020). Kerusakan-cagaralam-mandor-kian-meluas-duluhutan-kini-gurun. Retrieved September 28, 2020, from https://pontianakpost.co.id

Andrade, G. S. M., \& Rhodes, J. R. (2012). Protected areas and local communities: an inevitable partnership toward successful conservation strategies? Ecology and Society, 17(4).

Fancy, S. G., Gross, J. E., \& Carter, S. L. (2009). Monitoring the condition of natural resources in US national parks. Environmental Monitoring and Assessment, 151(1), 161-174.

Gross, J. E., Goetz, S. J., \& Cihlar, J. (2009). Application of remote sensing to parks and protected area monitoring: Introduction to the special issue. Remote Sensing of Environment, 113(7), 1343-1345.

Mashizi, A. K., \& Sharafatmandrad, M. (2020). Assessing ecological success and social acceptance of protected areas in semiarid ecosystems: a socio-ecological case study of Khabr National Park, Iran. Journal for Nature Conservation, 125898.

Mitsui, S., Kubo, T., \& Shoji, Y. (2020). Understanding residents' perceptions of nature and local economic activities using an openended question before protected area designation in Amami Islands, Japan. Journal for Nature Conservation, 125857.
Munir, A., Atmosoemarto, M., \& Arifien, Y. (2019). Perubahan Tutupan Lahan Hutan di Cagar Alam Rawa Danau Mengunakan Citra Lansat dan Ssistem Informasi Geografis. Jurnal Nusa Sylva, 17(1), 19-28.

Nahib, I., \& Wijaya, J. (1999). Aplikasi Inderaja dan SIG untuk Monitoring Keberhasilan Reboisasi di Kabupaten Kupang Propinsi Nusa Tenggara Timur. Jurnal Manajemen Hutan Tropika, 5(2).

Nordiansyah, H. (2016). Penilaian Efektivitas Pengelolaan Kawasan Konservasi di Kawasan Cagar Alam Padang Luway Kabupaten Kutai Barat. Agrifor, 15(1), 43-54.

Oldekop, J. A., Holmes, G., Harris, W. E., \& Evans, K. L. (2016). A global assessment of the social and conservation outcomes of protected areas. Conservation Biology, 30(1), 133-141.

Rahayu, S. (2017). Pemanfaatan Penginderaan Jauh Untuk Pengelolaan Bentang Lahan Karst. ResearchGate.

Ratnawati, E. (2020). cagar-alammandor-kawasan-suaka-alam-iturusak-akibat-peti. Retrieved September 28, 2020, from https://www.mongabay.co.id/2015/ $06 / 25 / \mathrm{c}$

Soliku, O., \& Schraml, U. (2018). Making sense of protected area conflicts and management approaches: A review of causes, contexts and conflict management strategies. Biological Conservation, 222, 136-145.

Tesfaye, Y., Bekele, M., Kebede, H., Tefera, F., \& Kassa, H. (2015). Enhancing the Role of Forestry in Building Climate Resilient Green Economy in Ethiopia: Strategy for Scaling up Effective forest Management Practices in Oromia 
National Regional State with Emphasis on Participatory forest Management.

Verdoodt, A., Mureithi, S. M., \& Van Ranst, E. (2010). Impacts of management and enclosure age on recovery of the herbaceous rangeland vegetation in semi-arid Kenya. Journal of Arid Environments, 74(9), 1066-1073.

Wang, Y., Lu, Z., Sheng, Y., \& Zhou, Y. (2020).

Sensing
Applications in Monitoring of Protected Areas. Multidisciplinary Digital Publishing Institute.

Wang, Y., Mitchell, B. R., NugranadMarzilli, J., Bonynge, G., Zhou, Y., \& Shriver, G. (2009). Remote sensing of land-cover change and landscape context of the National Parks: A case study of the Northeast Temperate Network. Remote Sensing of Environment, 113(7), 1453-1461. 